\title{
IMPLEMENTASI ACTIVE KNOWLEDGE SHARING PADA PEMBELAJARAN SISTEM PERSAMAAN LINEAR DUA VARIABEL
}

\author{
Titut Wulandari ${ }^{1}$ \\ ${ }^{1}$ SMA Negeri 1 Magetan \\ Jalan Monginsidi No 24, Nganten, Selosari, Magetan, Indonesia. \\ E-mail: titutwulandari72@gmail.com, Telp: +6285731141330
}

\begin{abstract}
Abstrak
Tujuan dari penelitian ini adalah untuk: (1) mendeskripsikan tahapan implementasi strategi pembelajaran Active Knowledge Sharing pada pembelajaran SPLTV. (2) mengetahui tingkat respon siswa terhadap implementasi strategi pembelajaran Active Knowledge Sharing. Jenis penelitian ini adalah deskriptif eksploratif dengan pendekatan kualitatif. Data yang digunakan ada dua macam. Data pertama adalah data skor angket respon siswa. Data kedua adalah dokumen Rencana Pelaksanaan Pembelajaran (RPP) dan Lembar Kegiatan Siswa (LKS). Metode pengumpulan data yang digunakan yaitu metode dokumentasi, dan metode angket. Langkah pembelajaran SPLTV dengan Strategi Active Knowledge Sharing sebagai berikut. (1) guru menyiapkan daftar pertanyaan yang berkaitan dengan materi (2) guru membentuk kelompok yang beranggotakan 4 orang. (3) guru membagikan pertanyaan yang ditujukan kepada masing-masing kelompok. (4) guru meminta siswa untuk menjawab pertanyaan. (5) guru meminta salah satu siswa dari masing-masing kelompok untuk menyebar di dalam ruangan, mencari siswa dari kelompok lain yang dapat menjawab pertanyaan yang mereka tidak bisa menjawabnya. (6) guru meminta siswa untuk kembali ke tempat kelompoknya semula. (7) guru bersama-sama siswa membahas jawaban yang telah mereka dapatkan. (8) guru bersama siswa menyimpulkan materi. (9) guru memberikan evaluasi. Pelaksanan pembelajaran memiliki tingkat keberhasilan baik, artinya siswa merasa terbantu dan tertarik pada pembelajaran SPLTV dengan metode Active Knowledge Sharing.
\end{abstract}

Kata kunci : Active Knowledge Sharing, Pembelajaran aktif

\section{THE IMPLEMENTATION OF ACTIVE KNOWLEDGE SHARING IN TWO VARIABLE LINEAR EQUATION SYSTEM}

\begin{abstract}
The objectives of this study were (1) describe the step of the implementation of Active Knowledge Sharing, (2) to know the students' respond level of the implementation of Active Knowledge Sharing. This was the explorative descriptive with qualitative approach. The data were questionnaire score of students' responds and the document of lesson plan and student sheet. Data collection method were documentation and questionnaire method. The steps of lesson with the Active Knowledge Sharing were (1) the teacher prepared the list of questions based on the material, (2) the teacher made the group of student with 4 student in each group, (3) the teacher gave the questions for each group, (4) the teacher asked the student to answer the questions, (5) the teacher asked one of the student of each group to look for the student in group that can answer the questions, (6) the teacher asked the student to go back to their group, (7) the teacher and the students discuss about the questions, (8) the teacher and the students made the conclusion together, (9) the teacher gave the evaluation. The lesson went well that have the level of success in good, it means the students feel helpful and interest with the lesson that using Active Knowledge Sharing.
\end{abstract}

Keywords: Active Knowledge Sharing, active lesson, two variable linear equation system 


\section{PENDAHULUAN}

Satriawati, Musyrifah, dan Purwanto (2018: 45) menyatakan bahwa rata- rata kemampuan komunikasi matematik siswa yang diajarkan dengan strategi Active Knowledge Sharing lebih tinggi dari ratarata kemampuan komunikasi matematika siswa yang diajarkan dengan metode konvensional. Satriawati, Musyrifah, dan Purwanto (2018: 45) juga menyatakan bahwa lima standar proses pembelajaran matematika yang harus dimiliki oleh siswa yang diungkapkan dalam buku Principles and Standards for School Mathematics yaitu problem solving, reasoning and proof, communication, connection and representation. Standar proses tersebut diharapkan dapat meningkatkan kemampuan siswa dalam pembelajaran matematika.

Rusnilawati

(2016:

mengambangkan perangkat pembelajaran bercirikan Active Knowledge Sharing dengan pendekatan saintifik dalam upaya meningkatkan pengetahuan, kemampuan pemecahan masalah, dan sikap terhadap matematika. Hasil validasi menunjukkan perangkat yang dikembangkan layak digunakan dengan kategori sangat baik. Hasil uji coba menunjukkan bahwa perangkat yang dikembangkan praktis dan efektif. Ketuntasan belajar secara klasikal sudah mencapai Kriteria Ketuntasan Minimal (KKM) $80 \%$ yaitu untuk tes pengetahuan mencapai $97,2 \%$, sedangkan tes pemecahan masalah mencapai 95,4\%. Berdasarkan angket sikap terhadap matematika, 98,1\% siswa menunjukkan peningkatan skor sikap terhadap matematika, dan $94,4 \%$ siswa menunjukkan sikap terhadap matematika dengan kategori minimal baik. Amril, Frimansyah, dan Wulandari (2017: 93) menyebutkan bahwa strategi Active Knowledge Sharing memberikan kesempatan kepada siswa untuk saling berbagi pengetahuan secara aktif. Kompetisi antar siswa dapat dikurangi karena siswa diajarkan untuk saling membantu teman dalam hal kegiatan belajar. Siswa diarahkan untuk berpikir kritis dan kreatif dalam menyelesaikan permasalahan matematika yang diberikan. Selain pada tingkat sikap terhadap matematika, kemampuan kognitif siswa juga mengalami peningkatan, namun persentase kenaikan kemampuan sikap siswa terhadap matematika lebih besar daripada persentase kenaikan kognitif siswa.

Berdasarkan beberapa hal di atas, maka akan diterapkan strategi pembelajaran Active Knowledge Sharing pada materi SPLTV.

\section{METODE}

Penelitian ini tergolong dalam penelitian penelitian deskriptif eksploratif dengan pendekatan kualitatif. Data penelitian yang diperoleh berupa angket respon siswa dan dokumen Rencana Pelaksanaan Pembelajaran (RPP) serta Lembar Kegiatan Siswa (LKS). Subyek penelitian ini adalah siswa kelas X IPS 1 SMA Negeri 1 Magetan pada semester Gasal Tahun Pelajaran 2019/2020. Data yang digunakan dalam penelitian ini ada dua macam. Data pertama adalah data tes tertulis yang diperoleh dari angket respon siswa. Data kedua adalah dokumen RPP dan LKS yang mengarah pada strategi Active Knowledge Sharing.

Instrumen bantu yang digunakan berupa Angket Respon siswa terhadap implementasi strategi pembelajaran Active Knowledge Sharing pada pembelajaran SPLTV. Selain angket, digunakan pulan metode dokumentasi. Dokumen yang dikumpulkan berupa perangkat pembelajaran SPLTV.

Metode pengumpulan data yang digunakan yaitu metode dokumentasi, dan metode angket. Metode dokumentasi digunakan untuk mengumpukan data pada identifikasi permasalahan Metode angket digunakan untuk mengetahui respon siswa terhadap pembelajaran. Perangkat pembelajaran SPLTV, dan angket respon siswa harus melalui penilaian pakar (expert judgement) sebelum digunakan. Setelah 
dilakukan expert judgement oleh dua orang pakar (validator), dihitung nilai hasil validasi dari setiap validator untuk mengetahui kevalidan instrumen. Nilai validasi $\left(\mathrm{N}_{\mathrm{V}}\right)$ dirumuskan sebagai berikut.

$$
\mathrm{N}_{\mathrm{V}}=\frac{\text { Total Nilai }}{\text { Banyak Indikator }}
$$

Tahap selanjutnya adalah menentukan Tingkat Validitas instrumen. Tingkat Validitas $\left(\mathrm{T}_{\mathrm{V}}\right)$ ditentukan dengan cara menghitung rata-rata nilai validasi dari seluruh validator. Kriteria Validitas terlihat pada tabel 1.

\begin{tabular}{cc}
\multicolumn{2}{c}{ Tabel 1. Kriteria Validitas } \\
\hline Rata-rata & $\begin{array}{c}\text { Tingkat } \\
\text { Validitas }\end{array}$ \\
\hline $4 \leq \mathrm{T}_{\mathrm{V}} \leq 5$ & Sangat valid \\
$3 \leq \mathrm{T}_{\mathrm{V}}<4$ & Valid \\
$2 \leq \mathrm{T}_{\mathrm{V}}<3$ & Kurang valid \\
$1 \leq \mathrm{T}_{\mathrm{V}}<2$ & Tidak valid \\
\hline
\end{tabular}

Angket respon siswa berisi pertanyaan mengenai perasaan siswa selama pembelajaran dan pendapat siswa mengenai pelaksanaan pembelajaran dihitung dengan menggunakan persentase keberhasilan indikator ketertarikan siswa secara klasikal. Penentuan indeks ketertarikan siswa ditentukan berdasar Tabel 2 .

Tabel 2. Indeks Ketertarikan siswa

\begin{tabular}{cc}
\hline Rata-rata & $\begin{array}{c}\text { Tingkat } \\
\text { Keberhasilan }\end{array}$ \\
\hline $90 \%<\mathrm{IK}_{\mathrm{M}} \leq 100 \%$ & Sangat baik \\
$80 \%<\mathrm{IK}_{\mathrm{M}} \leq 90 \%$ & Baik \\
$70 \%<\mathrm{IK}_{\mathrm{M}} \leq 80 \%$ & Cukup \\
$60 \%<\mathrm{IK}_{\mathrm{M}} \leq 70 \%$ & Kurang \\
$0 \%<\mathrm{IK}_{\mathrm{M}} \leq 60 \%$ & Sangat kurang \\
\hline
\end{tabular}

\section{HASIL DAN PEMBAHASAN}

Validasi oleh pakar (expert judgement) dilakukan untuk menyusun LKS dan angket respon siswa. Validasi dilakukan oleh dua orang pakar. Setelah dilakukan expert judgement oleh dua orang pakar (validator), dihitung nilai hasil validasi dari setiap validator untuk mengetahui kevalidan instrumen. Rangkuman Nilai validasi $\left(\mathrm{N}_{\mathrm{V}}\right)$ dan Tingkat Validitas $\left(\mathrm{T}_{\mathrm{V}}\right)$ terlihat pada tabel 3 dan 4.

Tabel 3. Hasil Validasi LKS

\begin{tabular}{ccc}
\hline & $\begin{array}{c}\text { Validator } \\
\text { I }\end{array}$ & $\begin{array}{c}\text { Validator } \\
\text { II }\end{array}$ \\
\hline Skor Total & 23 & 22 \\
Banyak Indikator & 5 & 5 \\
Nv & 4,6 & 4,4 \\
Tv & \multicolumn{2}{c}{4,5} \\
Kriteria Tingkat & \multicolumn{2}{c}{ Sangat Valid } \\
Validitas Produk & \multicolumn{2}{c}{} \\
\hline
\end{tabular}

Tabel 4. Hasil Validasi Angket Respon siswa

\begin{tabular}{ccc}
\hline & $\begin{array}{c}\text { Validat } \\
\text { or I }\end{array}$ & $\begin{array}{c}\text { Validator } \\
\text { II }\end{array}$ \\
\hline Skor Total & 20 & 23 \\
Banyak Indikator & 5 & 5 \\
Nv & 4 & 4,6 \\
Tv & \multicolumn{2}{c}{4,3} \\
Kriteria Tingkat & \multicolumn{2}{c}{ Sangat Valid } \\
Validitas Produk & \multicolumn{2}{c}{} \\
\hline
\end{tabular}

Berdasarkan hasil validasi diperoleh informasi bahwa LKS dan angket respon siswa sangat valid sehingga layak untuk digunakan.

Langkah pembelajaran SPLTV dengan Strategi Active Knowledge Sharing yaitu: (1) guru menyiapkan daftar pertanyaan yang berkaitan dengan materi pembelajaran yang diajarkan. Daftar Pertanyaan yang dibuat adalah sebagai berikut. (2) guru membentuk kelompok yang beranggotakan 4 orang. (3) guru membagikan pertanyaan yang ditujukan kepada masing-masing kelompok. (4) guru meminta siswa untuk menjawab pertanyaan. (5) guru meminta salah satu siswa dari masing-masing kelompok untuk menyebar di dalam ruangan, mencari siswa dari kelompok lain yang dapat menjawab pertanyaan yang mereka tidak bisa menjawabnya. Pada kegiatan ini guru mendorong siswa untuk membagi pengetahuan mereka secara aktif. (6) guru meminta siswa untuk kembali ke tempat kelompoknya semula. (7) guru bersama-sama siswa membahas jawaban yang telah mereka dapatkan. (8) guru 
bersama siswa menyimpulkan materi. (9) guru memberikan evaluasi.

Angket respon siswa terdiri atas delapan pertanyaan yang harus dijawab siswa dengan memilih ya dan tidak. Untuk pernyataan positif, jawaban ya bernilai 1 dan jawaban tidak bernilai nol. Sebaliknya, untuk pernyataan negatif, jawaban ya bernilai 0 dan jawaban tidak bernilai 1 .

Berdasarkan angket yang disebarkan secara acak ke kelas yang terdiri dari 10 siswa, diperoleh hasil seperti yang ditunjukkan pada tabel 5 .

Tabel 5. Hasil Angket siswa

\begin{tabular}{cccc}
\hline Ket & Data & IK & Kesimpulan \\
\cline { 1 - 2 } $\begin{array}{c}\text { Total } \\
\text { skor }\end{array}$ & 69 & & \\
\cline { 1 - 2 } $\begin{array}{c}\text { Skor } \\
\text { maksimal }\end{array}$ & 80 & 86,25 & $\begin{array}{c}\text { Tingkat } \\
\text { keberhasilan: } \\
\text { Baik }\end{array}$ \\
$\begin{array}{c}\text { Banyak } \\
\text { siswa }\end{array}$ & 10 & & \\
\hline
\end{tabular}

Berdasarkan hasil di atas, diperoleh bahwa pelaksanan pembelajaran dengan Kombinatorik memiliki tingkat keberhasilan baik, artinya siswa merasa terbantu dan tertarik pada pembelajaran.

Majid \& Chitra (2013, p.1201) menjelaskan bahwa "...active knowledge sharing, brings many benefits to students such as better academic achievements, improved communication and interpersonal skills, appreciation for diverse ideas and viewpoints, positive inter-dependence, and a sense of satisfaction for contributing towards learning of others". Pernyataan tersebut menjelaskan bahwa Active Knowledge Sharing membawa banyak manfaat bagi siswa seperti prestasi akademik yang lebih baik, peningkatan komunikasi dan keterampilan interpersonal, penghargaan untuk ide-ide dan sudut pandang yang beragam, saling ketergantungan yang positif, dan rasa kepuasan untuk memberikan kontribusi terhadap belajar dari orang lain. Hal ini sejalan dengan hasil penelitian yang menunjukkan bahwa tingkat ketertarikan siswa tinggi.
Freeman, et al (2013, pp.8413-8414) menjelaskan "active learning engages students in the process of learning through activities and/or discussion in class, as opposed to passively listening to an expert. It emphasizes higherorder thinking and often involves group work". Artinya belajar aktif melibatkan siswa dalam proses pembelajaran melalui kegiatan dan/atau diskusi di kelas. Kegiatan pembelajaran menekankan berpikir tingkat tinggi dan sering melibatkan kerja kelompok. Pernyataan tersebut sejalan dengan kondisi pembelajaran SPLTV.

Zain (2012, p.319) menjelaskan bahwa "...the learning skills were demonstrated in StudentCentred Learning through students' heightened interaction and cooperation, in and outside of the classroom, better planning of the lesson and their learning". Artinya, keterampilan belajar dalam Student-Centred Learning disertai dengan interaksi dan kerjasama siswa yang meningkat, baik di dalam maupun di luar kelas, serta perencanaan yang lebih baik dalam pembelajaran. Keterampilan yang disebutkan di atas juga muncul pada materi SPLTV.

\section{SIMPULAN}

Langkah pembelajaran SPLTV dengan Strategi Active Knowledge Sharing sebagai berikut. (1) guru menyiapkan daftar pertanyaan yang berkaitan dengan materi pembelajaran yang diajarkan. (2) guru membentuk kelompok yang beranggotakan 4 orang. (3) guru membagikan pertanyaan yang ditujukan kepada masing-masing kelompok. (4) guru meminta siswa untuk menjawab pertanyaan. (5) guru meminta salah satu siswa dari masing-masing kelompok untuk menyebar di dalam ruangan, mencari siswa dari kelompok lain yang dapat menjawab pertanyaan yang mereka tidak bisa menjawabnya. Pada kegiatan ini guru mendorong siswa untuk membagi pengetahuan mereka secara aktif. (6) guru meminta siswa untuk kembali ke tempat kelompoknya semula. (7) guru bersama-sama siswa membahas jawaban yang telah mereka 
dapatkan. (8) guru bersama siswa menyimpulkan materi. (9) guru memberikan evaluasi. Pelaksanaan pembelajaran dengan Kombinatorik memiliki tingkat keberhasilan baik, artinya siswa merasa terbantu dan tertarik pada pembelajaran.

Studi beriktunya dapat dilajutkan dengan menerapkan strategi pembelajaran Active Knowledge Sharing dan pengaruhnya terhadap kemampuan komunikasi matematis, dan atau dengan variabel yang lain. Hal ini karena siswa memberikan respon baik terhadap pembelajaran sehingga diharapkan dampak akademis dan non akademik juga dapat dikaji kembali lebih mendalam.

\section{DAFTAR PUSTAKA}

Amril,L.O., Firmansyah, W., dan Wulandari, R.W. 2017. Strategi Active Knowledge Sharing Setting Pendekatan Saintifik untuk Meningkatkan Sikap Siswa Terhadap Matematika. Jurnal Sosial Humaniora. 8 (2), 93 -103.

Freeman, et al. 2013. Active learning increases student performance in science, engineering, and mathematics. Proceedings of the Nation Academy of Sciences, 111 (23)

Majid, S. \& Chitra P. K. 2013. Role of knowledge sharing in the learning process. Literacy Information and
Computer Education Journal

(LICEJ), 2(1), 1201-1207.

Rusnilawati, R. 2016. Pengembangkan Perangkat Pembelajaran Matematika Bercirikan Active Knowledge Sharing dengan Pendekatan Saintifik Kelas VIII. Jurnal Riset Pendidikan Matematika. 3(2), 245 - 258

Sari, E.F.P. 2016. Penerapan Model Active Knowledge Sharing dalam Pembelajran Matematika Siswa Kelas VII di SMP N 18 Palembang. Jurnal "Mosharafa", 5(3), 335-341

Satriawati, G, Musyrifah, E., Purwanto, S. 2018. Pengaruh Strategi Pembelajaran Active K nowledge $\mathrm{S}$ haring terhadap Kemampuan Komunikasi Matematik Siswa Jurnal Riset Pendidikan Matematika Jakarta. 1(1). 45-51

Silberman, M. 2013. Pembelajaran aktif, 101 strategi untuk mengajar secara aktif. (Terjemahan Sarjuli dkk) Boston, MA: Allyn and Bacon.

Zain, S. F. H. S., Farah E. M. R., \& Ismin I. Z. A. (2012). Student-centred learning in mathematics-constructivism in the classroom. Journal of International Education Research - Fourth Quarter 2012, 8(4), 319-328. 